\title{
EFEKTIFITAS TEKNIK RELAKSASI DAN DISTRAKSI TERHADAP INTENSITAS NYERI AKIBAT PERAWATAN LUKA LAPARATOMIDI RUANG BEDAH RSU DR. PIRNGADI MEDAN TAHUN 2014
}

\author{
Elny Lorensi Silalahi \\ Jurusan Keperawatan \\ Politeknik Kesehatan Kemenkes Medan Jalan Jamin Ginting KM 13,5
}

\begin{abstract}
Abstrak
Pada tahun 2012 di Indonesia, tindakan operasi mencapai 1,2 juta jiwa dan diperkirakan 32\% diantaranya merupakan tindakan bedah laparatomi. Data kasus laparatomi diruang bedah rumah sakit Dr.Pirngadi Medan tahun 2013 berjumlah 53 kasus dan data tahun 2014 sampai februari, terdapat 10 kasus laparatomi. Setiap pembedahan dapat menyebabkan ketidaknyamanan dan trauma bagi pasien. Manajemen nyeri merupakan salah satu cara yang digunakan dibidang kesehatan untuk mengatasi nyeri yang dialami pasien. Metode pereda nyeri non farmakologis merupakan tindakan mandiri perawat untuk mengurangi intensitas nyeri paska operasi seperti teknik relaksasi dan distraksi.Jenis penelitian ini adalah rancangan eksperimen semu (quasi experiment design) dengan one group pre post test design. Penelitian ini dilakukan di ruang rawat bedah rumah sakit Dr. Pirngadi Medan. Penelitian dilakukan mulai bulan 21 Januari 2014 sampai 4 Mei 2014. Dengan Jumlah responden sebanyak 10 orang. Hasil penelitian ini menunjukkan bahwa mayoritas responden adalah laki-laki sebanyak 6 (60\%) responden, umur 45-50 tahun sebanyak 5 (50\%) responden dan tidak memiliki riwayat operasi sebanyak 7 (70\%) responden.Dan berdasarkan hasil uji statistik menggunakan Paired T-test didapatkan Teknik relaksasi cukup efektif dalam menurunkan nyeri dengannilai $\mathrm{p}=0,000(\mathrm{p}<\alpha=0,05)$ sedangkan Teknik distraksi pada pasien laparatomi kurang efektif dalam menurunkan nyeri dengan nilai $\mathrm{p}=0,168(\mathrm{p}<\alpha=0,05)$.
\end{abstract}

Kata kunci: Laparatomi, Nyeri, Teknik Relaksasi dan Distraksi

\section{PENDAHULUAN}

Laparatomi adalah pembedahan melalui dinding perut atau abdomen yang melalui bagian kulit, fascia, otot, dan peritoneum.Luka laparatomi adalah luka bersih yang termasuk luka akut dimana proses penyembuhan lukanya akan berlangsung secara alami menurut fase penyembuhan luka (Jitowiyono, 2010).

Menurut data World Health Organization (WHO) (2013), jumlah pasien dengantindakan operasi mencapai angka peningkatan yang sangat signifikan. Pada tahun 2011 terdapat 140 juta pasien di seluruh rumah sakit di dunia, dan pada tahun 2012 diperkirakan meningkat menjadi 148 juta jiwa. Pada tahun 2012 di Indonesia, tindakan operasi mencapai 1,2 juta jiwa dan diperkirakan 32\% diantaranya merupakan tindakan bedah laparatomi (Kemenkes RI, 2013).

Data kasus laparatomi diruang bedah rumah sakit Dr.Pirngadi Medan tahun 2013 berjumlah 53 kasus dan data tahun 2014 sampai februari, terdapat 10 kasus laparatomi. Data ini menunjukan bahwa kasus laparatomi berdampak pada intervensi perawatan luka dirumah sakit. (Rekam Medis RSUD Dr. Pirngadi, 2014).

Setiap pembedahan dapat menyebabkan ketidaknyamanan dan trauma bagi pasien. Salah satu yang sering dikeluhkan klien adalah nyeri. Nyeri yang ditimbulkan oleh operasi biasanya membuat pasien merasa sangat kesakitan (Perry \& Potter 2010). Nyeri pada laparatomi merupakan nyeri akut yang memiliki awitan cepat dan berlangsung dalam waktu singkat yang terjadi karena adanya luka insisi bekas pembedahan yang menyebabkan tubuh menghasilkan mediator-mediator kimia nyeri (Potter \& Perry, 2010)..

Manajemen nyeri merupakan salahsatu cara yang digunakan dibidang kesehatan untuk mengatasi nyeri yang dialami pasien. Secara garis besar ada dua manajemen untuk mengatasi nyeri yaitu manajemen farmakologi dan non farmakologi (Smeltzer\& Bare, 2010).

Metode pereda nyeri nonfarmakologis merupakan tindakan mandiri perawat untuk mengurangi intensitas nyeri paska operasi seperti teknik relaksasi dan distraksi. Teknik relaksasi bertujuan untuk memberikan rasa nyaman dan rileks pada pasien, dapat mengurangi intensitas nyeri, serta dapat meningkatkan ventilasi paru dan meningkatkan oksigen darah. Sedangkan distraksi merupakan teknik memfokuskan perhatian pasien pada sesuatu selain pada nyeri dan merupakan mekanisme yang bertanggung jawab terhadap teknik kognitif efektif lainnya. Distraksi dapat menurunkan persepsi nyeri dengan menstimulasi sistem kontrol desenden, yang mengakibatkan lebih sedikit stimulinyeri yang di tranmisikan ke otak. Biasanya 
membutuhkan waktu 5-10 menit pelatihan sebelum pasien dapat meminimalkan nyeri secara efektif. Dimana tujuan pokok dari relaksasi adalah membantu pasien menjadi rileks dan memperbaiki berbagai aspek kesehatan fisik. Periode relaksasi yang teratur dapat membantu untuk melawan keletihan dan ketegangan otot yang terjadi dengan nyeri dan yang meningkatkan nyeri (Smeltzer \& Bare, 2010).

Penelitian Pinandita, dkk (2012) tentang Pengaruh Teknik Relaksasi Genggam Jari TerhadapPenurunan Intensitas Nyeri Pada Pasien Post Operasi Laparatomi di RS PKU Muhammadiyah Gombong Tahun 2011 menemukan bahwa terdapat pengaruh teknikrelaksasi genggam jari terhadap penurunan intensitas nyeri pada pasien post operasilaparatomi dengan perbedaan ratarata intensitas nyeri pre test-posttest pada kelompok eksperimen adalah 1.764 dan perbedaan rata-rata intensitas nyeri pre test-post test pada kelompok kontrol adalah 0.117 dan nilai $\mathrm{p}=0.000(\mathrm{p}<0.05)$.

\section{METODE}

Jenis penelitian ini adalah rancangan eksperimen semu (quasi experiment design) dengan one group pre post test design. Penelitian ini dilakukan di ruang rawat bedah rumah sakit Dr. Pirngadi Medan. Penelitian dilakukan mulai bulan 21 Januari 2014 sampai 4 Mei 2014. Dengan Jumlah responden sebanyak 10 orang.

\section{HASIL}

\section{Analisis Univariat}

a. Karakteristik Responden

Tabel 4.1

Distribusi Frekuensi Responden Laparatomi Berdasarkan Jenis Kelamin di Ruang Bedah RSU Dr. Pirngadi Medan Tahun 2014

\begin{tabular}{|c|c|c|}
\hline Jenis Kelamin & F & \% \\
\hline Laki-laki & 6 & 60,0 \\
Perempuan & 4 & 40,0 \\
\hline Total & $\mathbf{1 0}$ & $\mathbf{1 0 0 , 0}$ \\
\hline
\end{tabular}

Berdasarkan tabel diatas dapat diketahui bahwa mayoritas $6(60,0 \%)$ responden berjeniskelamin Laki-laki.

Tabel 4.2

Distribusi Frekuensi Responden Laparatomi Berdasarkan Umur di Ruang Bedah RSU Dr. Pirngadi Medan Tahun 2014

\begin{tabular}{|c|c|c|}
\hline Umur & F & \% \\
\hline $20-35$ & 3 & 30.0 \\
$40-45$ & 2 & 20.0 \\
$45-50$ & 5 & 50.0 \\
& & \\
\hline Total & $\mathbf{1 0}$ & $\mathbf{1 0 0 . 0}$ \\
\hline
\end{tabular}

Berdasarkan tabel diatas dapat diketahui bahwa mayoritas 5 (50,0\%)responden berada pada kelompok umur 45-50 tahun.
Tabel 4.3

Distribusi Frekuensi Responden Laparatomi Berdasarkan Riwayat Operasi di Ruang Bedah RSU Dr. Pirngadi Medan Tahun 2014

\begin{tabular}{ccc}
\hline Riwayat Operasi & F & \% \\
\hline Ya & 3 & 30.0 \\
Tidak & 7 & 70.0 \\
\hline Total & $\mathbf{1 0}$ & $\mathbf{1 0 . 0}$ \\
\hline
\end{tabular}

Berdasarkantabel diatas dapat diketahui bahwa 7 (70,0\%) responden tidak memiliki riwayat operasi sebelumnya.

Tabel 4.4

Distribusi Frekuensi Responden Laparatomi

Berdasarkan Intensitas Nyeri Sebelum dilakukan

Teknik Relaksasi dan Distraksi di Ruang Bedah RSU Dr. Pirngadi Medan Tahun 2014

\begin{tabular}{ccc}
\hline Intensitas Nyeri & $\mathbf{F}$ & $\mathbf{\%}$ \\
\hline Sedang & 3 & 30.0 \\
Berat & 7 & 70.0 \\
\hline Total & $\mathbf{1 0}$ & $\mathbf{1 0 0 . 0}$ \\
\hline
\end{tabular}

Berdasarkan tabel diatas dapat diketahui bahwa 7 (70,0\%) responden mengalami intensitas nyeri berat sebelum dilakukan tindakan relaksasi dan distraksi.

Tabel 4.5

Distribusi Frekuensi Responden Laparatomi Berdasarkan Intensitas Nyeri Setelah dilakukan Teknik Relaksasi di Ruang Bedah RSU Dr. Pirngadi MedanTahun 2014

\begin{tabular}{ccc}
\hline Intensitas Nyeri & $\mathbf{F}$ & $\mathbf{\%}$ \\
\hline Ringan & 7 & 70.0 \\
Sedang & 3 & 30.0 \\
\hline Total & $\mathbf{1 0}$ & $\mathbf{1 0 0 . 0}$
\end{tabular}

Berdasarkan tabel diatas dapat diketahui bahwa 7 (70,0\%) responden mengalami penurunan intensutas nyeri menjadi ringan setelah dilakukan tindakan tindakan relaksasi.

Tabel 4.6

Distribusi Frekuensi Responden Laparatomi Berdasarkan Intensitas Nyeri Setelah dilakukan Teknik Distraksi di

Ruang Bedah RSU Dr. Pirngadi Medan Tahun 2014

\begin{tabular}{ccc}
\hline $\begin{array}{c}\text { Intensitas } \\
\text { Nyeri }\end{array}$ & $\mathbf{F}$ & $\mathbf{\%}$ \\
\hline Sedang & 5 & 50.0 \\
Berat & 5 & 50.0 \\
\hline Total & $\mathbf{1 0}$ & $\mathbf{1 0 0 . 0}$ \\
\hline
\end{tabular}

Berdasarkan tabel diatas dapat diketahui bahwa 5 (50,0\%) responden masih mengalami nyeri dengan intensitas berat setelah dilakukan tindakan relaksasi.

\section{Analisa Bivariat}

Analisis bivariat ini dilakukan menggunakan uji statistik Paired T-test pada tahap kepercayaan 95\% $(p<0.05)$ untuk melihat efektifitas teknik relaksasi dan distraksi terhadap intensitas nyeri akibat perawatan 
luka laparatomi di ruang bedah rumak sakit umum Dr. Pirngadi Medan tahun 2014.

Tabel 4.7

Distribusi Frekuensi Responden Laparatomi Berdasarkan Intensitas Nyeri Sebelum dan Sesudah dilakukan Teknik Relaksasi

\begin{tabular}{ccc}
\hline Intensitas Nyeri & F & \% \\
\hline Sebelum & & \\
\hline Sedang & 3 & 30.0 \\
Berat & 7 & 70.0 \\
\hline Sesudah & & \\
\hline Ringan & 7 & 70.0 \\
Sedang & 3 & 30.0 \\
\hline Total & $\mathbf{1 0}$ & $\mathbf{1 0 0 . 0}$
\end{tabular}

Berdasarkan tabel diatas dapat diketahui bahwasebelum dilakukan tindakan relaksasi7 responden (70.0\%) mengalami nyeri dengan intensitas berat dan setelah dilakukan tindakan relaksasi sebanyak 7 responden (70\%) mengalami nyeri dengan intensitas. Dari hasil uji statistik menggunakan Paired T-test didapatkan hasil $\mathrm{p}=0,000(\mathrm{p}<\alpha=0,05)$ sehingga dapat disimpulkan bahwa teknik relaksasi cukup efektif dalam menurunkan nyeri.

Tabel 4.8

Distribusi Frekuensi Responden Laparatomi Berdasarkan Intensitas Nyeri Sebelum dan Sesudah Dilakukan Teknik Distraksi

\begin{tabular}{ccc}
\hline $\begin{array}{c}\text { Intensitas } \\
\text { Nyeri }\end{array}$ & F & \% \\
\hline Sebelum & & \\
\hline Sedang & 3 & 30.0 \\
Berat & 7 & 70.0 \\
\hline Sesudah & & \\
\hline Ringan & 5 & 50.0 \\
Sedang & 5 & 50.0 \\
\hline Total & $\mathbf{1 0}$ & $\mathbf{1 0 0 . 0}$ \\
\hline
\end{tabular}

Berdasarkan tabel diatas dapat diketahui bahwa sebelum dilakukan tindakan distraksi 7 responden (70\%) mengalami nyeridengan intensitas berat dan setelah dilakukan tindakan distraksi sebanyak 5 responden (50.0\%)masih mengalami nyeri dengan intensitas berat. Dari hasil uji statistik dengan menggunakan Paired T-test dapat disimpulkan bahwa nilai $\mathrm{p}=0,168(\mathrm{p}<\alpha=0,05)$ yang berarti teknik distraksi pada pasien laparatomi kurang efektif dalam menurunkan nyeri.

\section{PEMBAHASAN}

Berdasarkan hasil penelitian didapat hasil untuk jenis kelamin mayoritas laki-laki, dan berdasarkan umur mayoritas responden berumur 45-50 tahun, sedangkan berdasarkan riwayat operasi mayoritas responden belum pernah mengalami operasi. Penelitian ini sebanding dengan teori Potter \& Perry, 2005, yang menyatakan bahwa nyeri merupakan sesuatu yang kompleks, sehingga banyak faktor yang dapat mempengaruhi respon seseorang terhadap nyeri seperti usia, kebudayaan, makna nyeri, perhatian pada nyeri, ansietas, kelelahan, pengalaman terdahulu, gaya koping dan dukungan keluarga.

Dapat dilihat perbandingan rata-rata intensitas nyeri sebelum dan sesudah dilakukan teknik relaksasi. Intensitas nyeri sebelum dilakukan teknik relaksasi, nyeri sedang 3(30,0\%)responden dan nyeri berat 7 (70,0\%) responden. Setelah dilakukan teknik relaksasi terjadi penurunan terhadap intesitas nyeri dimana nyeri ringan 7 (70,0\%)responden dan nyeri sedang 3 (30,0\%)responden. Melalui uji statistik Paired T-test terbukti bahwa nilai probabilitas $=0,000$ lebihkecil dari 0,05 berarti teknik relaksasi pada pasien laparatomi cukup efektifitas dalam menurunkan intensitas nyeri.

Dan pada teknik distraksi intensitas nyeri sebelum dilakukan teknik distraksi, nyeri sedang 3 (30,0\%) responden dan nyeri berat 7 (70,0\%)responden. Setelah dilakukan teknik distraksi nyeri ringan menjadi 5 (50,0\%)responden dan nyeri sedang menjadi 5 (50,0\%)responden. Melalui uji statistik Pared T-test terbukti bahwa nilai probabilitas = 0,168 lebih besar dari 0,05 berati teknik distraksi pada pasien laparatomi kurang efektifitas dalam menurunkan intensitas nyeri.

Perbedaan rata-rata intensitas nyeri yang dirasakan responden dimungkinkan dapat terjadi karena kemampuan setiap individu berbeda dalam merespon dan mempersepsikan nyeri yang dialami, keadaan ini dapat dihubungkan dengan karakteristik yang dimiliki oleh responden. Menurut Potter dan Perry (2005), kemampuan seseorang dalam mempersepsikan nyeri dipengaruhi oleh sejumlah faktor seperi usia, jenis kelamin, lingkungan, kecemasan dan lainlain. Dimana faktor-faktor tersebut dapat meningkatkan atau menurunkan persepsi nyeri, meningkatkan atau menurunkan toleransi terhadap nyeri, dan mempengaruhi sikap respons terhadap nyeri.

Penelitian sejalan dengan penelitian Pinandita, dkk (2012) tentang Pengaruh Teknik Relaksasi Genggam Jari TerhadapPenurunan Intensitas Nyeri Pada Pasien Post Operasi Laparatomi di RS PKU Muhammadiyah Gombong Tahun 2011 menemukan bahwa terdapat pengaruh teknikrelaksasi genggam jari terhadap penurunan intensitas nyeri pada pasien post operasilaparatomi dengan perbedaan rata-rata intensitas nyeri pre test-posttest pada kelompok eksperimen adalah 1.764 dan perbedaan rata-rata intensitas nyeri pre test-post test pada kelompok kontrol adalah 0.117 dan nilai $\mathrm{p}=0.000(\mathrm{p}<0.05)$.

Penelitian ini sebanding dengan teori Brunner \& Suddarth, 2013 yang menyatakan penanganan nyeri dapat dilakukan secara farmakologis dan nonfarmakologis. Penanganan farmakologis yaitu dengan menggunakan analgetik, steroid, NSAID dan penanganan nonfarmakologis yaitu teknik relaksasi dan teknik distraksi. Dalam penelitian ini melalui uji statistik Paired T-test terbukti bahwa nilai probabilitas $=0,000$ lebih kecil dari 0,05 berarti teknik relaksasi 
pada pasien laparatomi cukup efektifitas dalam menurunkan intensitas nyeri dibandingkan teknik distraksi.

\section{KESIMPULAN}

1. Teknik relaksasi cukup efektif dalam menurunkan nyeri dengan hasil uji statistik menggunakan Paired T-test didapatkan hasil $\mathrm{p}=0,000(\mathrm{p}<\alpha=$ $0,05)$

2. Teknik distraksi pada pasien laparatomi kurang efektif dalam menurunkan nyeri dengan hasil uji statistik dengan menggunakan Paired T-test dapat disimpulkan bahwa nilai $\mathrm{p}=0,168(\mathrm{p}<\alpha=0,05)$.

\section{SARAN}

\section{Bagi Rumah Sakit}

Kepada pihak RSUD Dr. Pirngadi khususnya di ruangan bedah agar teknik relaksasi dapat dijadikan prosedur tetap (protap) dalam penanganan pasien nyeri nonfarmakologis.

\section{Bagi Pasien dan Keluarga}

Dapat melakukan teknik relaksasi dan distraksi secara mandiri dalam upaya penanganan nyeri guna meningkatkan kenyamanan pasien.

\section{REFERENSI}

Arief Mansjoer, dkk. 2010. Kapita Selekta Kedokteran. Jakarta:Penerbit Aescalapus.

Asmadi. 2008. Konsep dan Aplikasi Kebutuhan Dasar Klien. Jakarta: Penerbit: Salemba Medika.

Aziz A. 2009. Metode Penelitian Keperawatan. Volume 2. Edisi 7. Penerbit Salemba Medika Jakarta.
Brunner \& Suddart. 2013. Keperawatan Medikal Bedah Edisi 8 Vol.2. Jakarta: EGC

Jitowiyono, S. 2010. Asuhan Keperawatan Post Operasi. Yogyakarta: Muha Medika

Kemenkes RI. (2013). Standar Pelayanan Minimal Rumah Sakit. Jakarta : Kemenkes

Kozier.2010.Fundamental Keperawatan. Volume 2. Edisi 7, Penerbit: EGC. Jakarta. 2010.

Moya J.Morison. 2004. Manajemen Luka. Penerbit: EGC Jakarta.

Notoatmodjo. 2012. Metodologi Penelitian Kesehatan. Penerbit: PT.Rineka Cipta Jakarta.

Nursalam. 2008. Konsep dan Penerapan Metodologi Penelitian Ilmu Keperawatan. Penerbit: Salemba Medika Jakarta.

Oswari. 2005 Bedah dan Perawatannya. FKUI Jakarta. Penerbit: Gaya Baru.

Potter Patricia A. 2010. Fundamental Keperawatan. Volume 1. Edisi 4. Penerbit: EGC Jakarta.

Pinandita, dkk (2012). Pengaruh Teknik Relaksasi Genggam Jari Terhadap Penurunan Intensitas Nyeri Pada Pasien Post Operasi Laparatomi di RS PKU Muhammadiyah Gombong Tahun 2011 Jurnal Ilmiah. Kesehatan Keperawatan, Volume 8, No. 1, Februari 2012

Smeltzer. 2010. Buku Ajar Keperawatan Medikal Bedah. Volume 1. Edisi 8. Penerbit: EGC Jakarta. Suriadi. 2004. Perawatan Luka. Edisi 1. Penerbit: CV.Sugen Seto Jakarta.

Tamsuri. 2006. Konsep dan Penatalaksanaan Nyeri. Penerbit: EGC Jakarta. 